\title{
PENGEMBANGAN WISATA BAHARI PANTAI MULUT SERIBU SEBAGAI DAYA TARIK WISATA BERKELANJUTAN DI KABUPATEN ROTE, NUSA TENGGARA TIMUR
}

\author{
Yudha Eka Nugraha dan Frengky Lussie \\ Email: yudhaekanugraha@gmail.com \\ POLITEKNIK NEGERI KUPANG
}

\begin{abstract}
East Nusa Tenggara Province surrounded by many potentials nature-based attractions, one of them is Mulut Seribu beach, in the Rote Ndao Regency. This beach is one of seven priority tourist attractions by the East Nusa Tenggara Provincial Government. Local Government initiation is welcomed by the local community and this research aims to create a strategy to develop the Mulut Seribu beach attraction with marine-based tourism to support sustainability. The research type is using descriptive qualitative, with interviewing stakeholders from five key informants living around the tourist attraction namely government representatives, tourists, and the local community. The results showed that according to SWOT analysis Mulut Seribu Beach is among Curve 1, which means the development of this destination still aggressive to be developed with a concentration of development in SO, namely strength and opportunity. This result is shown by the Mulut Seribu festival as a form of coordination between community and government participation in developing marine tourism in Mulut Seribu Beach.
\end{abstract}

Keywords: Marine Tourism, Tourism Development, Sustainable Tourism

\section{Abstrak}

Provinsi Nusa Tenggara Timur menyimpan berbagai keindahan alam yang potensial untuk menjadi sebuah daya tarik wisata, salah satunya di Kabupaten Rote Ndao yaitu Pantai Mulut Seribu. Pantai ini merupakan salah satu dari tujuh destinasi unggulan Pemerintah Provinsi Nusa Tenggara Timur. Sebagai destinasi unggulan, salah satu usaha pengembangannya adalah melalui penerapan wisata bahari yang disambut baik oleh masyarakat setempat sehingga penelitian ini bertujuan untuk membuat strategi pengembangan daya tarik wisata Pantai Mulut Seribu yang berbasis wisata bahari untuk mendukung pariwisata berkelanjutan. Jenis penelitian ini desktriptif kualitatif dengan Kepala Dinas Pariwisata Rote Ndao dan masyarakat setempat yang tinggal di sekitar daya tarik wisata Pantai Mulut Seribu. Hasil penelitian menunjukkan bahwa Daya 
Tarik Wisata Pantai Mulut Seribu dalam Kurva 1 yang berarti sedang berkembang secara agresif dengan konsentrasi pengembangan fokus di strategi SO, yaitu strength dan opportunity. Geliat perkembangan ini ditunjukkan dengan adanya festival mulut seribu sebagai bentuk promosi, partisipasi, dan kerjasama antara masyarakat dan pemerintah dalam mengembangkan wisata bahari di Pantai Mulut Seribu.

Kata Kunci: Wisata Bahari, Pengembangan Pariwisata, Wisata Berkelanjutan

\section{Pendahuluan}

Nusa Tenggara Timur merupakan salah satu provinsi di Republik Indonesia yang sedang melakukan pengembangan terutama dalam bidang Pariwisata. Baik pemerintah, swasta, maupun akademisi mulai melakukan pembangunan di bidang kepariwisataan. Menurut Arief Yahya, koordinasi dari berbagai stakeholders ini merupakan bagian dalam pentahelix pariwisata (Yahya, 2015).

Pengembangan kepariwisataan di NTT dibuktikan dengan keseriusan pemerintah setempat dengan membangun tujuh daya tarik wisata yang menjadi penyangga destinasi wisata unggulan (Damawa, 2019). Salah satu daya tarik wisata bahari yang dikembangkan adalah pantai yang letaknya strategis yaitu berada di Desa Daiama Kecamatan Landuleko Kabupaten Rote Ndao. Pantai ini dikenal dengan sebutan Pantai Mulut Seribu. Pantai ini berjarak 39 km dari pusat Kota Ba'a. Pantai Mulut Seribu dikenal sebagai salah satu pantai yang memiliki ombak yang tenang serta pasir putih yang bersih. Tidak hanya itu saja Pantai Mulut Seribu juga merupakan primadona bagi masyarakat khususnya Desa Daiama, karena mendatangkan wisatawan. Pantai Mulut Seribu yang mulai banyak dikunjungi wisatawan karena memiliki potensi dan peluang yang besar, dilihat oleh berbagai pihak sebagai kesempatan untuk mengembangkan daya tarik wisata tersebut. Salah satu upaya yang dilakukan oleh pemerintah adalah dengan melakukan pengembangan pariwisata 
berkelanjutan di Pantai Mulut Seribu dalam rangka mewujudkan destinasi unggulan di Kabupaten Rote Ndao. Sejak tahun 2019, pendampingan sudah mulai dilakukan oleh pemerintah provinsi bekerjasama dengan akademisi sehingga pengembangan sumber daya manusia pada Wisata Bahari di Pantai Mulut Seribu sedang dilakukan (Fandeli, 2005).

Proses pengembangan pariwisata Pantai Mulut Seribu memerlukan usaha yang serius untuk pelestarian dan pengembangkannya sehingga potensi wisata yang dimiliki Pantai Mulut Seribu berkelanjutan. Upaya ini dilakukan dalam rangka meningkatkan kesejahteraan masyarakat karena pada dasarnya pariwisata keberlanjutan berusaha mensinergikan aspek-aspek ekonomi, sosial budaya, dan lingkungan dalam pengembangan kepariwisataan (Nugraha, 2019). Pariwisata berkelanjutan lebih lanjut didefinisikan sebagai jenis pariwisata yang mengkalkulasikan penuh dampak ekonomi, sosial-budaya dan lingkungan. Jenis pariwisata ini bertujuan memenuhi kebutuhan wisatawan, industri, lingkungan dan masyarakat setempat.

Namun, kenyataan di lapangan berbeda, butuh proses yang Panjang untuk dapat mewujudkan pariwisata berkelanjutan. Pengembangan wisata bahari di Pantai Mulut Seribu penting dilakukan agar masing-masing stakeholder dapat mengoptimalkan perencanaan pembangunan pariwisata di Pantai Mulut Seribu. Sejauh ini, kesadaran wisata belum diterapkan sepenuhnya di wisata Mulut Seribu Desa Daiama Kecamatan Landuleko Kabupaten Rote Ndao, padahal, secara potensi atraksi, Wisata Bahari Mulut Seribu memiliki potensi istimewa seperti pemandangan alam, pantai yang bersih. Sayangnya, belum ada pihak yang bisa mengelola dengan baik sehingga masyarakat setempat perlu mendapatkan edukasi lebih lanjut mengenai sadar wisata. Kerusakan lingkungan juga bisa terjadi bila tidak dilakukannya perencanaan pengembangan yang tepat guna, dapat dilihat bahwa di daerah penduduk 
setempat terdapat penumpukan sampah dan limbah yang kurang sedap dipandang mata.

Pariwisata berkelanjutan juga terkait dengan potensi dari segi ekonomi. Dari sudut pandang ekonomi, pariwisata merupakan salah satu bidang yang bisa mendatangkan dampak positif secara langsung kepada masyarakat setempat. (Dewi, 2013) Dampak tersebut yakni peningkatkan taraf hidup masyarakat dan pendapatan masyarakat lokal itu sendiri. Manfaat ekonomi membutuhkan partisipasi masyarakat dalam kegiatan kepariwisataan misalnya saja dengan menyewakan perahu untuk wisatawan, membuat kerajinan tangan, menunjukkan keterampilan seni dan budaya masyarakat setempat, berjualan berbagai jenis makanan dan lain lain. Pada bidang sosial budaya, pariwisata berkelanjutan juga memiliki peran penting terutama dalam isu interaksi dan pertukaran perilaku yang terjadi. Interaksi antara wisatawan dan masyarakat lokal dapat memberikan dampak yang baik maupun yang buruk. Bahkan interaksi antara wisatawan dan masyarakat lokal dapat mengancam budaya setempat. (Haris, 2012) Sehingga, perumusan strategi pengembangan kawasan wisata bahari di pantai mulut seribu Kabupaten Rote merupakan prioritas yang tepat untuk dikerjakan oleh pentahelix pariwisata untuk mendukung pembangunan pariwisata berkelanjutan.

Sejauh ini, pemerintah provinsi telah melakukan promosi yang membuat nama Pantai Mulut Seribu dikenal oleh berbagai kalangan. Promosi tersebut dilakukan melalui event yang dilaksanakan pada 26-28 Oktober 2019 yaitu Festival Mulut Seribu. Dari sini terlihat bahwa pemerintah memiliki keseriusan untuk membangun destinasi ini sebagai salah satu prioritas pengembangan wisata. Festival ini menampilkan parade perahu hias, lomba dayung, tarian massal, lomba memainkan alat music sasando, lomba kabalai (tarian melingkar) dan lainnya. Kegiatan ini bila dikelola dengan baik maka akan mendatangkan keuntungan ekonomi 
bagi masyarakat setempat sehingga pengembangan wisata bahari Pantai Mulut Seribu harus dikelola dengan lebih serius. Tujuannya adalah menjaga destinasi wisata agar tetap dibangun dengan perencanaan yang tepat sasaran dan dampaknya memberikan tingkat kepuasan yang tinggi baik bagi wisatawan maupun masyarakat setempat.

Berdasarkan pemaparan sebelumnya, maka potensi daya tarik wisata Pantai Mulut Seribu di Kabupaten Rote Ndao memang sedang mendapatkan banyak perhatian, baik dari masyarakat setempat, wisatawan, akademisi, maupun pemerintah setempat. Hal ini ditunjukkan dengan kedatangan wisatawan yang terus menerus selama penelitian ini dilakukan. Sayangnya, pihak pengelola belum melakukan pencatatan akan kedatangan wisatawan. Ketiadaan pos penjaga, sampah yang masih berserakan, kurang sadarnya masyarakat setempat akan pentingnya pariwisata, maka penelitian ini akan dirumuskan berbagai usaha yang bisa dilakukan untuk mengoptimalkan pengembangan wisata bahari di Pantai Mulut Seribu.

\section{Konsep dan Teori}

\subsection{Wisata Bahari}

Wisata bahari merupakan salah satu subsektor kepariwisataan dalam menghasilkan kontribusi terhadap peningkatan pendapatan daerah dan juga memberikan kontribusi positif terhadap penguatan posisioning citra destinasi wisata suatu wilayah. Hal ini merupakan relevansi keunikan potensi wisata suatu daerah akan keberadaan potensi wisata bahari yang cenderung tidak dimiliki oleh daerah lain, sehingga memberikan peluang penting bagi suatu daerah untuk memperkuat citra destinasi wisata pada tingkat persaingan yang dihadapi.

Peraturan mengenai pariwisata tercantum dalam UU No. 10 Tahun 2009 tentang kepariwisataan, pengertian wisata bahari atau tirta adalah 
usaha penyelenggaraan wisata di air dan olahraga air ternasuk penyediaan sarana dan prasarana serta jasa pendukung lainnya yang dikelola dengan komersil di perairan laut, pantai, sungai, danau, dan waduk.

Wisata bahari merupakan aktivitas wisata yang terkait dengan pantai, laut, dan aktivitas yang dilakukan di wilayah pesisir dan perairan, (Nisyantara, 2011) wisata bahari merupakan kegiatan rekreasi di pantai atau lautan yang memiliki keunikan tersendiri sehingga menjadi daya tarik. Berdasarkan pengertian diatas dapat ditarik kesimpulan bahwa wisata bahari merupakan seluruh kegiatan yang bersifat rekreasi yang aktifitiasnya dilakukan pada media bahari atau kelautan yang meliputi daerah pantai, pulau-pulau yang ada disekitarnya, serta kawasan lautan yang ada di permukaan laut, didalamnya, ataupun dasar lautan termasuk didalamnya taman laut.

\subsection{Pariwisata Berkelanjutan}

Pariwisata berkelanjutan adalah jenis pendekatan yang berlawanan dengan mass tourism. Pendekatan pariwisata berkelanjutan mulai berkembang ditandai dengan pertambahan jumlah akomodasi, populasi masyarakat setempat dan keselarasan alam, dimana pengembangan pariwisata dan pembagunan investasi dalam sektor pariwisata seharusnya tidak membawa dampak negatif dan dapat menyatu dengan lingkungan, jika pengelola kepariwisataan memaksimalkan dampak yang positif dan meminimalkan dampak negatif. Pariwisata berkelanjutan memiliki beberapa prinsip-prinsip yaitu: a) Partisipasi; b) Keikutsertaan Para Pelaku/Stakeholder Involvement, c) Kepemilikan Lokal, d) Penggunaan Sumber Daya yang Berkelanjutan, e) Mewadahi Tujuan-Tujuan Masyarakat, f) Daya Dukung, g) Monitor dan Evaluasi, h) Akuntabilitas, i) Pelatihan. 
Menurut Harris Et Al (2012), pariwisata berkelanjutan adalah bentuk kepariwisataan yang harus dikelola dengan mematuhi batas wajar, yang tetap memperhatikan tidak hanya aspek ekonomi, sosial, dan juga lingkungan, tetapi juga menopang dan memelihara hal tersebut. Sementara itu, UNWTO (2016) mengartikan pariwisata berkelanjutan sebagai pariwisata yang memperhatikan dampak dari berbagai aspek seperti: dampak ekonomi, sosial-budaya, dan lingkungan saat ini dan nanti di masa depan, menjawab kebutuhan pengunjung, industri (pariwisata), lingkungan dan komunitas tuan rumah.

Dengan demikian maka dapat disimpulkan bahwa pariwisata berkelanjutan merupakan pariwisata harus ramah lingkungan dan dapat dinikmati oleh generasi yang akan datang. Menurut WTO untuk industri travel dan pariwisata menyatakan Sustainable Development Tourism memenuhi kebutuhan wisatawan dan masyarakat daerah tujuan wisata sambil melindungi dan mengembangkan peluang pada masa depan. Dipandang sebagai sesuatu yang mengarahkan ke manajemen, seluruh sumber daya dimana kebutuhan ekonomi, sosial dan estetik dapat dipenuhi bersama integritas budaya, proses-proses ekologi yang esensial, dan sistem-sistem mendukung kehidupan tetap terpelihara. Strategi dalam Sustainable Tourism adalah sebagai berikut: a) Meningkatkan tanggung jawab stakeholder corporate; b) Menghasilkan bentuk pariwisata yang cocok, c) "sustaining” sumber daya sosial dam budaya, d) "sustaining” lingkungan alam, e) Kebutuhan atas rencana yang efektif untuk perencanaan daerah tujuan wisata, f) Peranan Carrying Capatities dan indikator-indikator dalam Sustainable Tourism (Suansri,2003), g) Menghindari konflik, h) Peningkatan keterlibatan masyarakat, i) Pengarahan untuk masa depan. 


\section{Metode Penelitian}

Jenis penelitian yang cocok diterapkan dalam penelitian ini adalah deskriptif kualitatif. Penelitian deskriptif kualitatif digunakan untuk menjelaskan fenomena yang dialami oleh subjek dalam sebuah penelitian misalnya dari segi perilaku, presepsi, tindakan, secara menyeluruh, dengan cara mendeskripsikannya dalam bentuk kata-kata dan bahasa, tergantung pada konteks penelitian sesuai dengan standar alamiah dan dengan pemanfaatkan berbagai metode ilmiah (Moleong 2007). Penelitian ini menggunakan dua jenis data yaitu yang pertama data primer yang diperoleh secara langsung dari sumbernya (Lewsi, 2003) yaitu dari Kantor Dinas Kebudayaan dan Pariwisata Kabupaten Rote Ndao dan masyarakat setempat, Teknik yang dilakukan dengan observasi (Creswell 2008) dan wawancara mendalam. Kedua adalah data sekunder merupakan data yang tidak langsung, misalnya melalui artikel, data statistik buku, dan dokumen laporan pemerintahan.

Teknik pengumpulan data menggunakan metode Purposive Sampling dengan pertimbangan tertentu. Pertimbangan tertentu ini misalnya, orang tertentu tersebut yang dianggap paling tahu tentang apa yang diharapkan, sehingga akan memudakan proses pengumpulan data. (Sugiyono, 2015) Informan dalam penelitian ini terdiri dari 5 informan yaitu: 1) Kepala Bidang Pengembangan destinasi, 2) Kepala Bidang Promosi, 3) Kepala Desa Daiama, 4) Ketua Kelompok Sadar Wisata dan 5) Masyarakat Lokal. Pemilihan informan dalam penelitian ini didasarkan pada orang-orang yang dipandang mampu memberikan informasi yang selengkap-selengkapnya dan berkaitan dengan bidang yang di teliti, sehingga data yang diperoleh dapat diakui kebenarannya. Selain observasi dan wawancara, juga dilakukan pengumpulan dokumentasi untuk memperkuat hasil penelitian. 


\section{Hasil Penelitian}

\subsection{Gambaran Daya Tarik Wisata Pantai Mulut Seribu}

Daya tarik wisata (DTW) pantai Mulut Seribu terletak di Desa Daiama Kecamatan Landu Leko Kabupaten Rote Ndao Provinsi Nusa Tenggara Timur. Jarak Desa Daiama dengan Pemerintah Kecamatan sejauh $5 \mathrm{~km}$, dengan pusat pemerintah Kota Ba'a sejauh $39 \mathrm{~km}$. DTW Pantai Mulut Seribu juga berada di kawasan Suaka Margamatwa Harlu dengan luas 2.262 ha. Secara geografis pantai Mulut Seribu di Desa Daiama merupakan daerah pesisir, daratannya berbukit dengan ketinggian dari permukaan laut \pm 150 Meter. Secara administratif DTW Pantai Mulut Seribu dikelilingi oleh tiga Desa yaitu Desa Pukuafu, Desa Lifuleo dan Desa Tena Lai.

Pantai Mulut Seribu memiliki udara yang sejuk karena dinaungi banyak pohon lontar yang hingga kini masih produktif. Pantainya berpasir putih halus, lautnya biru, airnya jernih dengan debur ombak yang bergulung-gulung kecil dan tenang. Pantai Mulut Seribu mempunyai topografi menarik, keseluruhan kawasan ini mempunyai variasi unik, yaitu perpaduan antara perbukitan dan pantai. Di sisi timur terdapat hutan mangrove (bakau) yang tumbuh rapat dan di dalamnya terdapat aneka satwa, mulai dari burung sampai rusa.

\subsection{Potensi Alam dan Bahari Pantai Mulut Seribu}

Pantai Mulut Seribu dikenal sebagai suatu DTW yang kaya akan potensi alamiah dengan pantai yang berpasir putih, ombak yang tenang dan mempunyai banyak tebing, batu karang disekitarnya seperti membentuk gua dan terlihat mempunyai banyak "mulut" merupakan panorama alam yang sangat indah menjadi DTW utama bagi masyarakat setempat dan wisatawan. Ketika wisatawan yang berkunjung ke pantai Mulut Seribu pada sore hari, juga bisa melihat panorama alam matahari terbenam 
(sunset) yang indah dan di tepi pantai rindangnya pohon mangrove yang menawarkan daya tarik tersendiri bagi wisatawan. Adapun aktivitas aktivitas yang bisa dilakukan oleh para wisatawan/pengunjung di pantai Mulut Seribu seperti rekreasi di tepi pantai dan duduk santai menikmati pemandangan alam, mandi, selam, makan minum khas daerah dan fotografi.

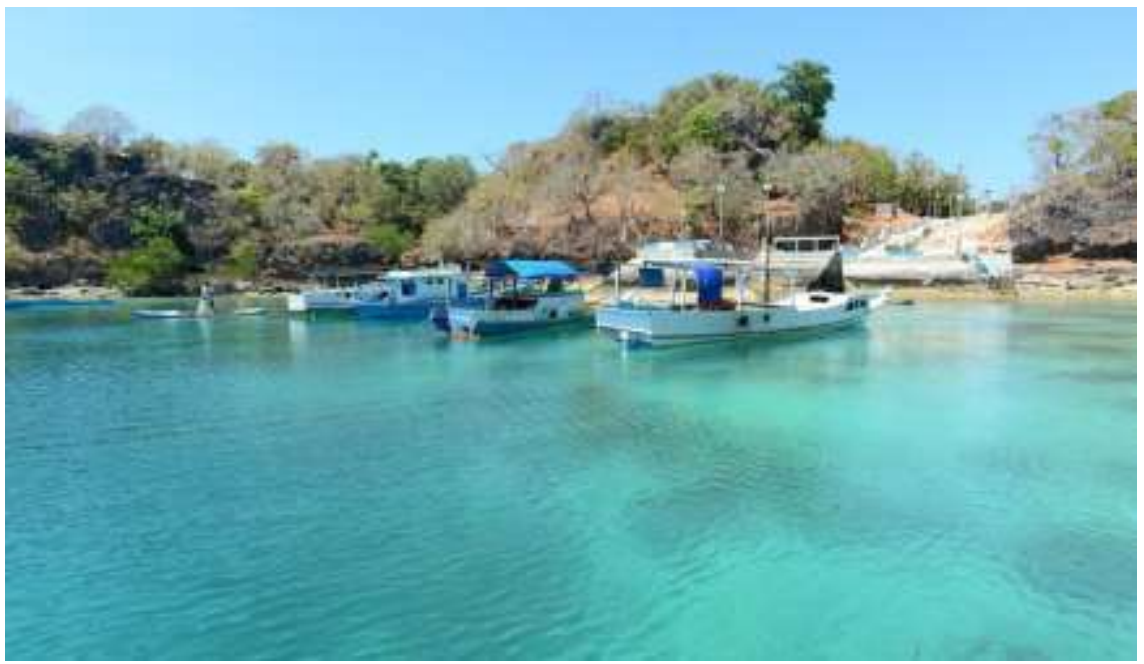

Gambar 1. Pantai Mulut Seribu, Sumber: detik.com

Potensi alam yang paling menarik bagi wisatawan untuk datang ke daya tarik wisata Pantai Mulut Seribu ini adalah lautnya. Pantai Mulut Seribu ini memiliki air yang jernih dan tenang. Awal mula disebut mulut seribu karena pantai ini memilki banyak tebing dan karang sehingga membentuk seperti mulut. Jika ingin melakukan petualangan lebih lanjut, kegiatan pariwisata biasanya dilakukan melalui transportasi laut, mengelilingi teluk mulut seribu. Jika dilihat dari atas, maka akan terlihat keindahan gugus-gugus pulau kecil yang membentuk teluk mulut seribu. Potensi wisata bahari di pantai ini ditunjukkan dengan ramainya peserta festival mulut seribu yang melakukan perlombaan kapal hias, dan lomba mendayung. Terdapat juga hamparan bakau yang menjadi tempat hidup bagi binatang-binatang darat maupun laut. Masyarakat biasa 
memanfaatkan ketenangan dari pantai ini dengan melakukan pembudidayaan rumput laut.

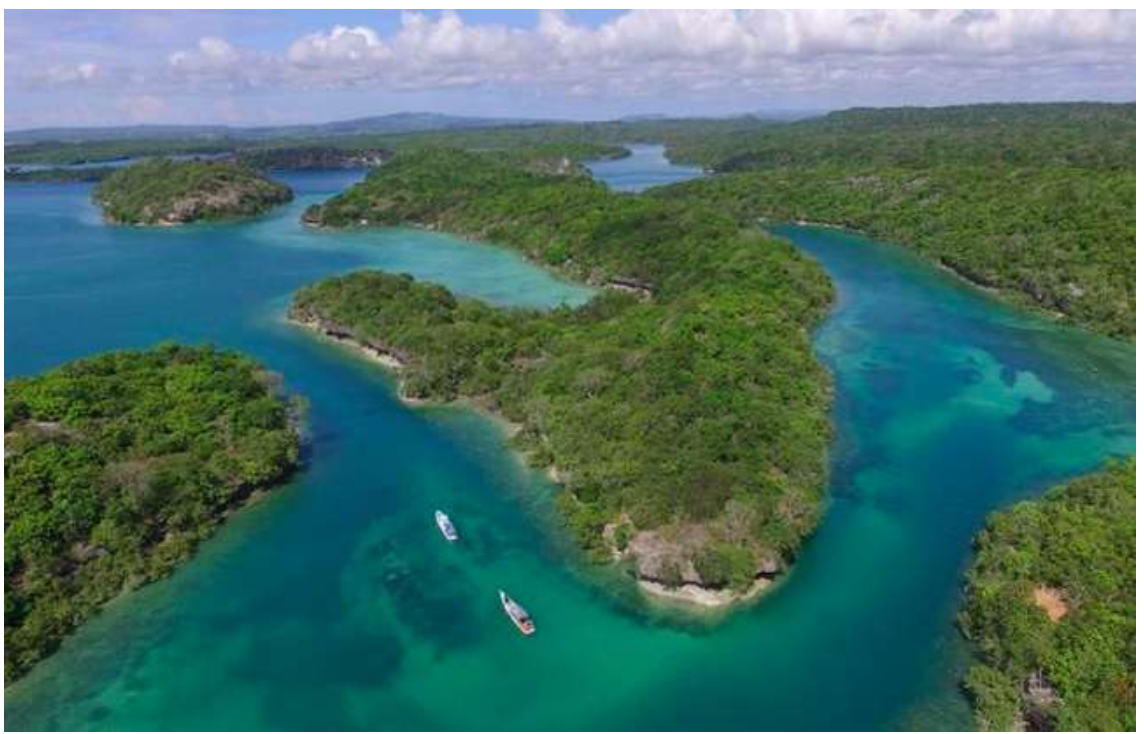

Gambar 2. Potensi Wisata Bahari Mulut Seribu,

Sumber: Dokumentasi Peneliti, 2019

\subsection{Potensi Budaya Pantai Mulut Seribu}

Pantai Mulut Seribu disamping memiliki potensi alam, juga memiliki potensi budaya dari kehidupan sosial budaya masyarakat lokal yang unik dan bisa dijadikan sebagai DTW yang menjadi pendukung potensi utama, yaitu pemanfaatan tanaman lontar menjadi berbagai barang kerajinan seperti alat musik sasando, pengelolaan air yang disadap dari pohon lontar menjadi gula. Pada pagi dan sore hari jika wisatawan berkunjung ke Pantai Mulut Seribu, wisatawan juga bisa melihat dan menyaksikan masyarakat setempat melakukan pemanjatan pohon lontar yang unik dan menarik. Adapun makanan tradisional yang disediakan oleh masyarakat lokal di lokasi wisata Pantai Mulut Seribu kepada wisatawan/pengunjung. Biasanya wisatawan/pengunjung yang berkunjung ke Pantai Mulut Seribu sebagian besar mencicipi makanan tradisional yang 
disebut pisang gepe (pisang bakar). Makanan tradisional ini juga bisa dimakan dengan dicampur dengan gula merah yang berbentuk cair atau istilahnya gula air yang diambil dan disadap dari pohon lontar masyarakat, pelestarian alam lingkungan dan sumber daya lainnya di lokasi Pantai Mulut Seribu.

Selain tanaman lontar ada juga tenun sarung yang di jadikan oleole bagi wisatawan/pengunjung. Alat pembuatan sarung masih manual yang di pakai masyarakat untuk menenun sarung. Dimulai dari mempersiapkan bahan utamanya yaitu benang yang akan dipakai. Biasanya menggunakan benang sutera yang terkenal halus. Setelah benang siap, proses selanjutnya adalah mewarnai benang tersebut berdasarkan fungsinya, apakah akan digunakan sebagai kain dasaran atau motif. Proses persiapan benang dengan pewarnaannya juga cukup panjang karena harus mewarnai benang dengan warna dasar putih. Setelah itu masuk pada proses penjemuran benang sarung. Setelah selesai, proses selanjutnya masuk pada proses pembuatan motif. Benang akan dibentangkan pada sebuah berukuran 1x1 meter lalu ditalikan dari ujung ke ujung membentuk pola sarung yang diinginkan.

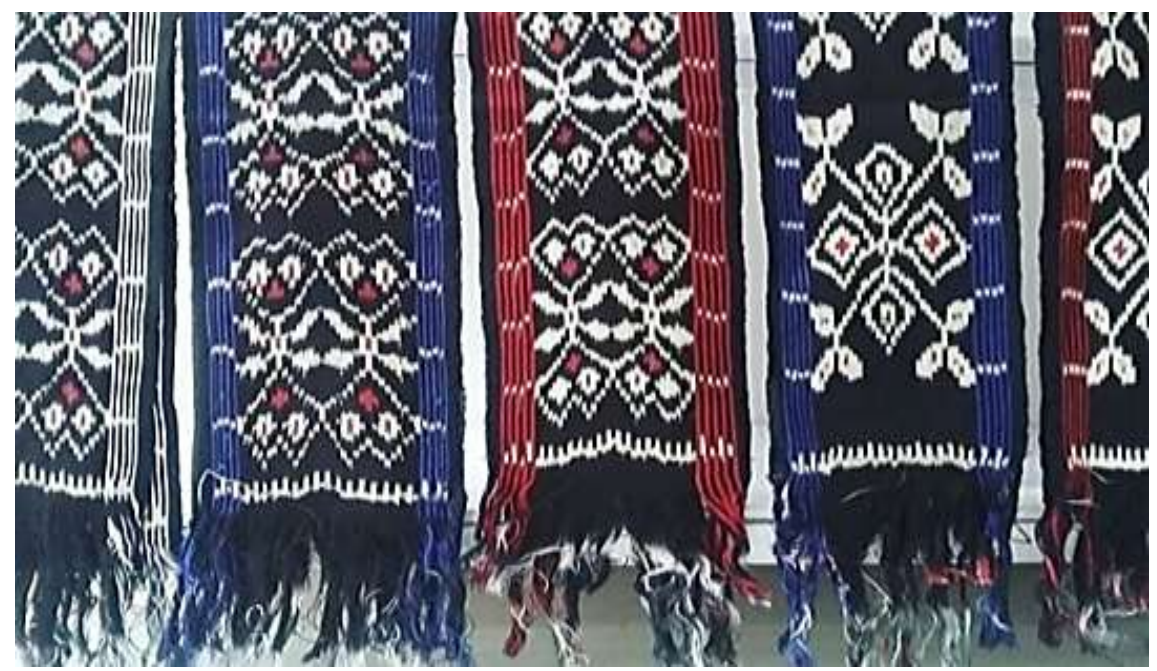

Gambar 3. Kain Tenun Rote, Sumber: Dokumentasi Peneliti, 2019 
Setelah selesai, benang akan ditali menggunakan rafia untuk selanjutnya masuk dalam proses pencelupan warna secara berulang sesuai dengan banyaknya warna yang dibutuhkan. Setelah pewarnaan benang sesuai warna motif ini selesai, benang dijemur hingga kering lalu digulung. Gulungan benang ini kemudian siap masuk proses penenunan. Ketika proses penenunan kain sarung sudah selesai, yang perlu dilakukan pada tahapan akhir adalah penjahitan dan pencucian. Penjahitan ini juga dilakukan dengan manual sehingga ini dapat membedakan sarung tenun dengan sarung pabrikan. Tenun merupakan daya tarik tersendiri bagi masyarakat lokal dan juga menjadi pendapatan ekonomi bagi masyarakat setempat. Selain tenun, potensi budaya lain yang menjadi kebanggaan masyarakat Kabupaten Rote Ndao adalah alat music sasando. Masyarakat setempat memanfaatkan tanaman lontar untuk membuat alat musik sasando, dibentuk kemudian menjadi sebuah alat music yang dapat mengeluarkan suara dengan cara dipetik. Alat musik ini merupakan suatu daya tarik tersendiri bagi masyarakat lokal terutama berkaitan dengan pelestarian budaya menggunakan bahan yang ramah lingkungan.

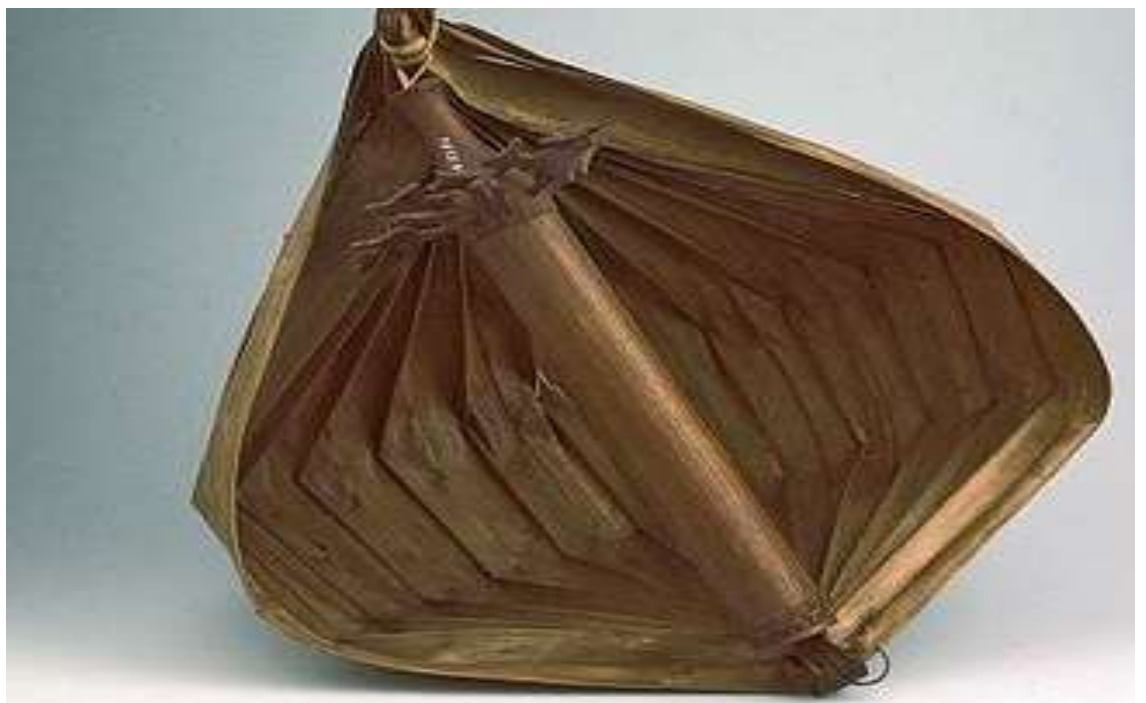

Gambar 4. Alat Musik Tradisional Sasando,

Sumber: Dokumentasi Peneliti, 2019 


\subsection{Kondisi Aksesibilitas, Amenitas dan Ancilliary}

Akses menuju DTW Pantai Mulut Seribu sangat mudah dijangkau dari Kota Ba'a karena jalan raya yang sudah baik. Kendaraan bisa disewa dari masyarakat setempat dimana kendaraan roda empat berharga sewa 300 ribu rupiah dan roda dua seharga 150 ribu rupiah. Setelah sampai di destinasi Pantai Mulut Seribu, wisatawan dapat langsung menikmati pemandangan alam atau bermain di pantai.

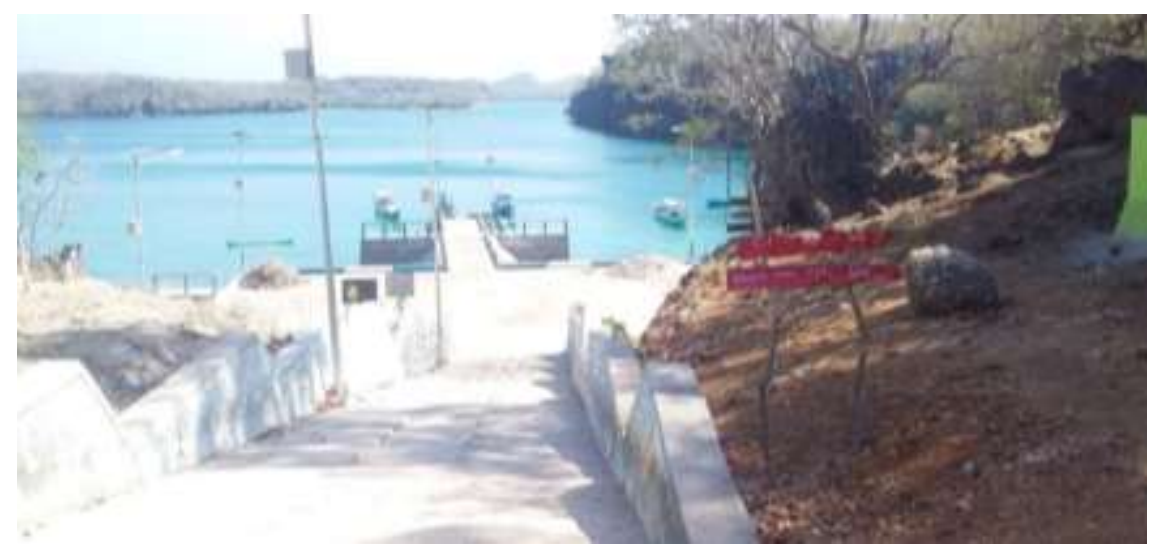

Gambar 5. Akses Pantai Mulut Seribu Yang Sudah Bagus,

Sumber: Dokumentasi Peneliti, 2019

Beberapa jenis amenitas tersedia di destinasi ini. DTW Pantai

Mulut Seribu memiliki usaha pariwisata penyedia makanan dan minuman kepada wisatawan berupa kantin milik masyarakat setempat. Kantin itu menyediakan berbagai makanan lokal untuk wisatawan. Makanan yang ditawarkan kebanyakan makanan setempat sehingga wisatawan tidak hanya menikmati keindahan alam tetapi juga dapat menikmati makanan lokal masyarakat setempat.

Pantai Mulut Seribu memilki 3 buah tempat sampah yang disediakan oleh masyarakat lokal sehingga wisatawan yang berkunjung tidak membuang sampah sembarangan tempat begitu juga masyarakat setempat. Terdapat lampu penerangan yang disediakan di area sekitar DTW Pantai Mulut Seribu. Masyarakat dan wisatawan/pengunjung bisa beraktivitas sampai malam hari dan bisa menikmati makanan disediakan 
oleh masyarakat lokal. Terdapat dua kamar mandi (Toilet/MCK) sederhana yang disediakan di area sekitar DTW Pantai Mulut Seribu. Wisatawan/pengunjung bisa menggunakan toilet tersebut jika ingin cuci muka dan mandi.

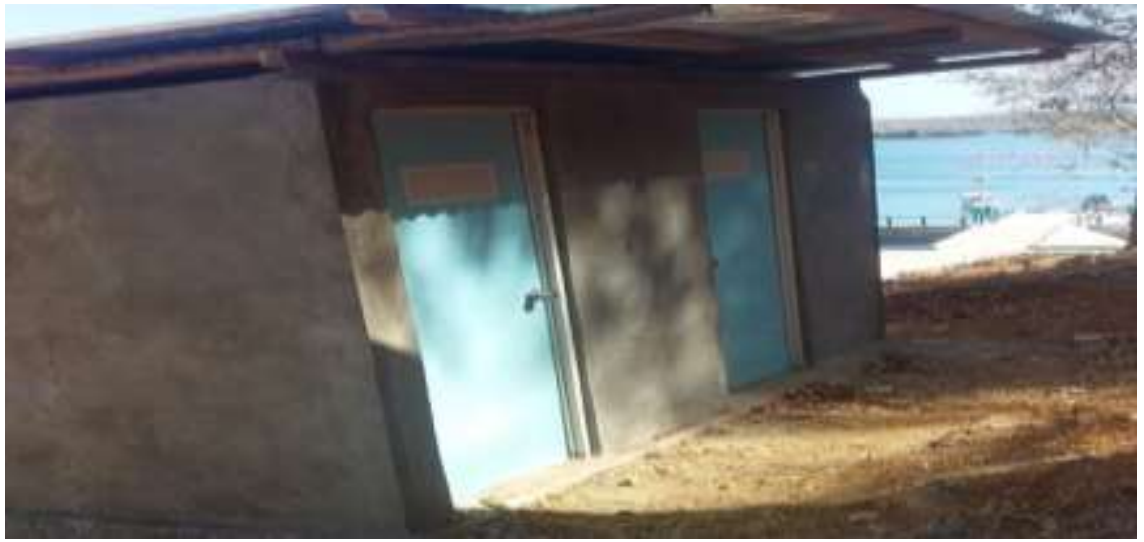

Gambar 6. Toilet, Sumber: Dokumentasi Peneliti, 2019

Dari segi ancilliary, pemerintah Kabupaten Rote Ndao, memiliki peran utama dalam pengembangan dan pegelolaan potensi dan DTW tersebut. Pihak instansi atau lembaga pemerintah yang mengelola seluruh potensi dan DTW yang ada di Kabupaten Rote Ndao adalah Dinas Kebudayaan dan Pariwisata Kabupaten Rote Ndao, melaksanakan pendampingan bagi masyarakat bekerjasama dengan akademisi dan pengelolaan daya tarik wisata Pantai Mulut Seribu melalui kegiatan festival yang diadakan setiap tahunnya.

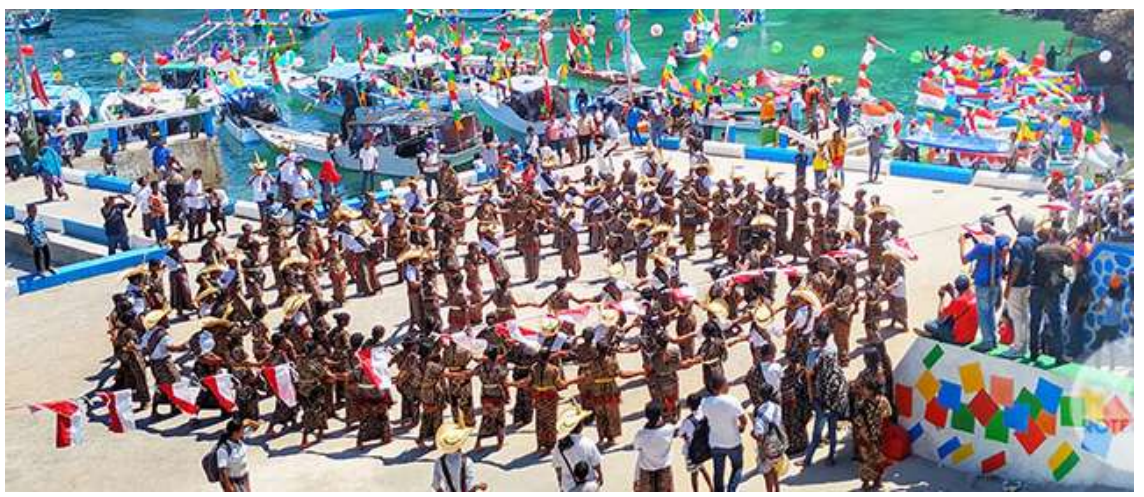

Gambar 7. Festival Mulut Seribu, Sumber: roolnews.id 


\section{Pembahasan}

Pembahasan dalam pengembangan wisata bahari pantai Mulut Seribu menggunakan dua Teknik analisis. Pertama dengan menggunakan pengelompokan matriks IFAS dan EFAS kemudian kedua menggunakan Teknik analisis SWOT (Rangkuti, 2006). Berikut adalah deskripsi faktorfaktor strategis internal (IFAS) dan faktor-faktor strategis eksternal (EFAS).

Tabel 1 Faktor-Faktor Strategis Internal (IFAS)

\begin{tabular}{lccc}
\hline \multicolumn{1}{c}{ Faktor-Faktor Strategi Internal } & Bobot & Rank & Skor \\
\hline \multicolumn{1}{c}{ Kekuatan (Strengths) } & & & \\
\hline 1. Potensi Wisata Bahari, Berlayar diantara tebing & 0.15 & $\mathbf{4 . 0 0}$ & $\mathbf{0 . 6 0}$ \\
\hline 2. Potensi wisata budaya sasando dan tenun Rote & 0.10 & $\mathbf{3 . 5 0}$ & $\mathbf{0 . 3 5}$ \\
\hline 3. Keindahan sunset saat matahari terbenam & 0.11 & $\mathbf{4 . 0 0}$ & $\mathbf{0 . 4 4}$ \\
\hline 4. Keramahan Masyarakat Lokal & 0.11 & $\mathbf{4 . 0 0}$ & $\mathbf{0 . 4 4}$ \\
\hline 5. Memiliki spot foto sebagai daya tarik buatan & 0.05 & $\mathbf{3 . 5 0}$ & $\mathbf{0 . 1 7}$ \\
\hline 6. Ketersediaan Amenitas berupa Homestay & 0.07 & $\mathbf{3 . 7 5}$ & $\mathbf{0 . 2 6}$ \\
\hline 7. Ketersediaan amenitas berupa kantin dan toilet & 0.08 & $\mathbf{3 . 5 0}$ & $\mathbf{0 . 2 8}$ \\
\hline \multicolumn{1}{c}{ Kelemahan (Weakness) } & & & \\
\hline 1. Lemahnya kualitas SDM di bidang pariwisata & 0.08 & $\mathbf{3 . 0 0}$ & $\mathbf{0 . 2 4}$ \\
\hline 2. Sampah yang menumpuk di beberapa spot & 0.08 & $\mathbf{3 . 0 0}$ & $\mathbf{0 . 2 4}$ \\
\hline 3. Tidak ada pemandu wisata setempat & 0.05 & $\mathbf{4 . 0 0}$ & $\mathbf{0 . 2 0}$ \\
\hline 4. Kurangnya keterlibatan stakeholders & 0.07 & $\mathbf{2 . 7 5}$ & $\mathbf{0 . 1 9}$ \\
\hline 5. Kegiatan wisata yang belum terstruktur & 0.05 & $\mathbf{2 . 5 0}$ & $\mathbf{0 . 1 2}$ \\
\hline \multicolumn{1}{c}{ TOTAL } & $\mathbf{1 . 0 0}$ & & $\mathbf{3 . 5 3}$ \\
\hline
\end{tabular}

Tabel 2 Faktor-Faktor Strategis Eksternal (EFAS)

\begin{tabular}{|c|c|c|c|}
\hline Faktor-Faktor Strategi Eksternal & Bobot & Rank & Skor \\
\hline \multicolumn{4}{|l|}{ Peluang (Opportunites) } \\
\hline 1. Perkembangan teknologi informasi dan komunikasi & 0.14 & 3.25 & 0.46 \\
\hline 2. Potensi kerjasama dengan jaringan pelaku pariwisata & 0.10 & 3.25 & 0.35 \\
\hline $\begin{array}{l}\text { 3. Pantai Mulut Seribu memiliki branding yang mulai dikenal } \\
\text { sebagai icon wisata di Rote }\end{array}$ & 0.15 & 4.00 & 0.60 \\
\hline 4. Pariwisata yang menjadi pengembangan prioritas NTT & 0.11 & 3.50 & 0.38 \\
\hline 5. Minat masyarakat melakukan kegiatan wisata & 0.09 & 3.50 & 0.32 \\
\hline 6. Penciptaan lapangan kerja bagi masyarakat setempat & 0.08 & 3.50 & 0.28 \\
\hline \multicolumn{4}{|l|}{ Ancaman (Threats) } \\
\hline 1. Krisis ekonomi global yang membuat wisatawan menurun & 0.06 & 4.00 & 0.24 \\
\hline 2. Persaingan objek wisata di tempat lain yang lebih kompetetif & 0.10 & 1.25 & 0.12 \\
\hline 3. Masuknya budaya luar mengikis budaya lokal & 0.08 & 2.25 & 0.18 \\
\hline $\begin{array}{l}\text { 4. Kebijakan internasional seperti travel warning ke destinasi } \\
\text { tertentu }\end{array}$ & 0.09 & 2.50 & 0.22 \\
\hline TOTAL & 1.00 & & 3.15 \\
\hline
\end{tabular}


Tabel 3 Matriks Internal-Eksternal

Posisi Strategis Pengembangan Wisata Bahari Pantai Mulut Seribu

Kabupaten Rote Ndao

Total Nilai IFAS

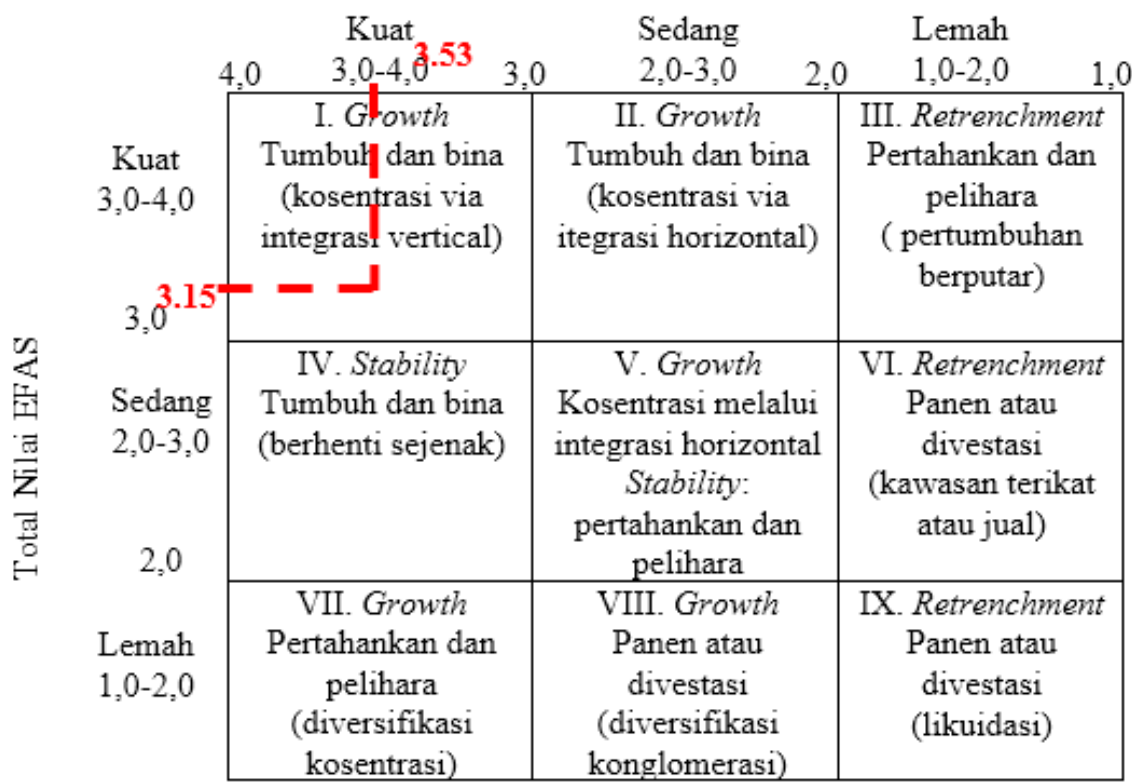

Sumber: IFAS dan EFAS

Tabel 4 Matrik Analisis SWOT Pengembangan Wisata Bahari Pantai Mulut Seribu Kabupaten Rote

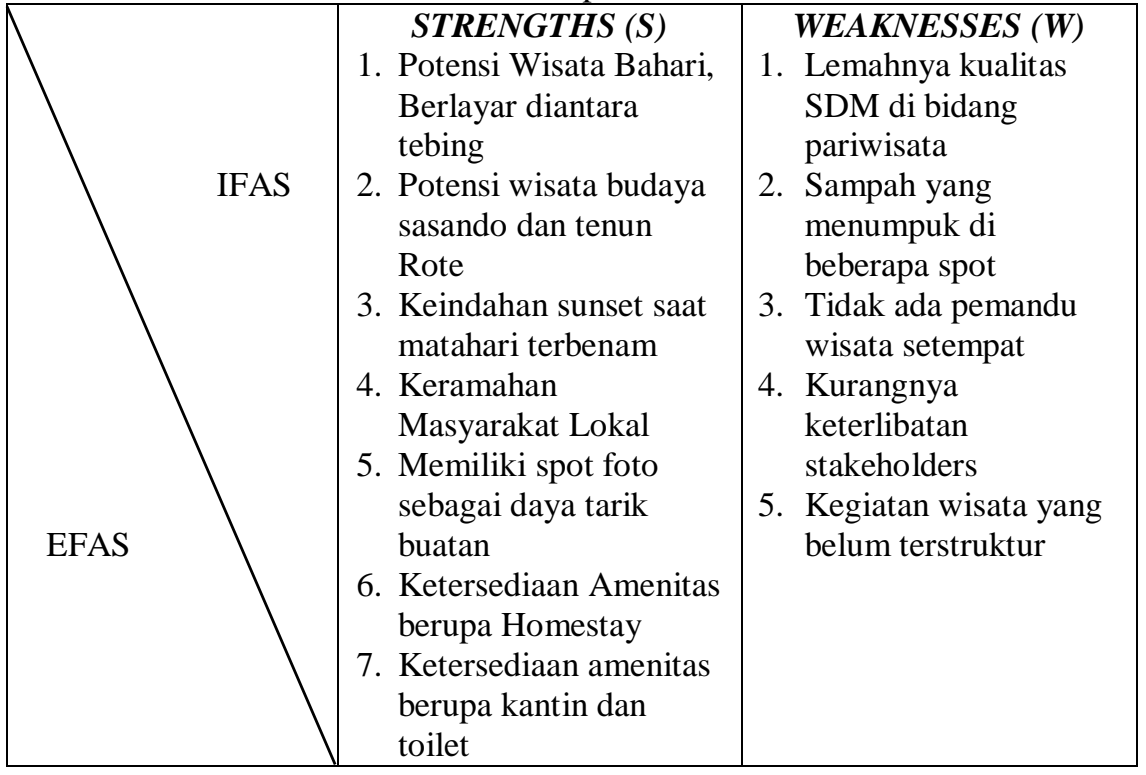




\begin{tabular}{|c|c|c|}
\hline $\begin{array}{l}\text { OPPORTUNITIES }(\boldsymbol{O}) \\
\text { 1. Perkembangan } \\
\text { teknologi } \\
\text { informasi dan } \\
\text { komunikasi } \\
\text { 2. Potensi } \\
\text { kerjasama dengan } \\
\text { jaringan pelaku } \\
\text { pariwisata } \\
\text { 3. Pantai Mulut } \\
\text { Seribu memiliki } \\
\text { branding yang } \\
\text { mulai dikenal } \\
\text { sebagai icon } \\
\text { wisata di Rote } \\
\text { 4. Pariwisata yang } \\
\text { menjadi } \\
\text { pengembangan } \\
\text { prioritas NTT } \\
\text { 5. Minat masyarakat } \\
\text { melakukan } \\
\text { kegiatan wisata } \\
\text { 6. Penciptaan } \\
\text { lapangan kerja } \\
\text { bagi masyarakat } \\
\text { setempat } \\
\text { THREATS (T) } \\
\text { Krisis ekonomi } \\
\text { global yang } \\
\text { membuat } \\
\text { wisatawan } \\
\text { menurun } \\
\text { 2. Persaingan objek } \\
\text { wisata di tempat } \\
\text { lain yang lebih } \\
\text { kompetetif } \\
\text { 3asuknya } \\
\text { budaya luar } \\
\text { mengikis budaya } \\
\text { lokal } \\
\text { Kebijakan } \\
\text { internasional } \\
\text { seperti travel } \\
\text { warning ke } \\
\text { destinasi tertentu }\end{array}$ & $\begin{array}{l}\text { STRATEGI SO } \\
\text { 1. Semakin meningkat } \\
\text { dan melestarikan } \\
\text { lingkungan serta } \\
\text { keaslian aset yang ada. } \\
\text { 2. Menyediakan produk } \\
\text { pariwisata yang dapat } \\
\text { mendukung kegiatan } \\
\text { pariwisata misal } \\
\text { jajanan lokal. } \\
\text { 3. Kerjasama antara } \\
\text { masyarakat dengan } \\
\text { pemerintah Kabupaten } \\
\text { Rote Ndao serta } \\
\text { pelaku-pelaku usaha } \\
\text { pariwisata } \\
\text { 4. Melakukan event-event } \\
\text { pariwisata yang } \\
\text { melibatkan masyarakat } \\
\text { lokal untuk proses } \\
\text { pengembangan SDM } \\
\text { 5. Meningkatkan } \\
\text { partisipasi dan peran } \\
\text { masyarakat lokal } \\
\text { dalam pembangunan } \\
\text { pariwisata. } \\
\text { STRATEGI ST } \\
\text { 1. Memelihara keaslian } \\
\text { dan keunikan budaya } \\
\text { yang dimiliki. } \\
\text { 2. Menjaga dan } \\
\text { melestarikan } \\
\text { keindahan alam. } \\
\text { 3. Selalu menjaga dan } \\
\text { membudayakan sapta } \\
\text { pesona } \\
\text { 4. Meningkatkan } \\
\text { keramahan masyarakat } \\
\text { lokal sehingga } \\
\text { wisatawan semakin } \\
\text { merasa nyaman dan } \\
\text { betah. }\end{array}$ & $\begin{array}{l}\text { STRATEGI WO } \\
\text { 1. Perlu adanya Local } \\
\text { Guide untuk } \\
\text { menjelaskan kepada } \\
\text { wisatawan yang } \\
\text { datang berkunjung } \\
\text { baik itu wisatawan } \\
\text { asing maupun } \\
\text { wisatawan lokal } \\
\text { 2. Mengembangkan } \\
\text { pengetahuan umum } \\
\text { maupun ketrampilan } \\
\text { berbahasa Indonesia } \\
\text { maupun asing } \\
\text { sehingga dapat } \\
\text { berkomunikasi } \\
\text { dengan wisatawan } \\
\text { dengan baik } \\
\text { Menyediakan } \\
\text { kendaraan beroda dua } \\
\text { sebagai salah satu } \\
\text { alternatif transportasi. }\end{array}$ \\
\hline
\end{tabular}

Sumber: Hasil Penelitian, 2020 


\subsection{Strategi Pengembangan Pariwisata Berkelanjutan}

Berdasarkan hasil analisis IFAS dan EFAS, maka pengembangan wisata bahari di Pantai Mulut Seribu berada pada quadran 1 yang berarti growth dan berkembang secara agresif. Berdasarkan hasil analisis SWOT maka strategi pengembangan pariwisata berkelanjutan pada DTW pantai mulut seribu, dapat diperoleh rumusan strategi sebagai berikut:

a. Strategi S-O (Strength-Opportunity)

Strategi ini merupakan prioritas, berdasarkan hasil analisis SWOT, dilakukan dengan melestarikan potensi dan daya tarik wisata terutama bahari dan budaya sehingga tetap menarik untuk dikunjungi wisatawan. Selain itu, diperlukan inisiasi yang terus menerus dalam bekerjasama antara masyarakat dengan pemerintah Kabupaten Rote Ndao serta pelaku-pelaku usaha pariwisata. Misalnya dengan melakukan event-event pariwisata yang melibatkan masyarakat lokal untuk proses pengembangan SDM. Seperti Festival Mulut Seribu yang telah dilaksanakan yang bertujuan untuk meningkatkan promosi terhadap Pantai Mulut Seribu. Kegiatan ini mendatangkan dampak positif salah satunya dari segi ekonomi yang dirasakan oleh masyarakat setempat. Langkah strategi selanjutnya yaitu dengan meningkatkan partisipasi masyarakat setempat karena masyarakat memiliki antusias tinggi dalam mengembangkan daya tarik wisata dibuktikan dengan suksesnya kegiatan festival mulut seribu.

b. Strategi W-O (Weakness-Opportunity)

Meningkatkan kunjungan wisatawan yang berkunjung di Pantai Mulut Seribu dilakukan dengan pengadaan local guide untuk memberikan wawasan kepada wisatawan yang datang berkunjung mengenai destinasi wisata Pantai Mulut Seribu. Sehingga wisatawan tidak hanya mengetahui tentang bentuk atau karakteristik pantai Mulut Seribu saja tetapi mendapat pengetahuan mengenai sejarah yang ada 
di pantai Mulut Seribu. Pengadaan pemandu lokal ini akan mengembangkan pengetahuan umum maupun ketrampilan berbahasa Indonesia maupun asing sehingga kedepan warga dapat berkomunikasi dengan baik ketika melakukan pemanduan wisata. Selain itu, dalam strategi ini, perlu adanya sarana transportasi tambahan sebagai pendukung kegiatan pariwisata.

c. Strategi S-T (Strength-Threat)

Melestarikan potensi dan daya tarik wisata yang dimiliki oleh pantai Mulut Seribu melalui pemeliharaan keaslian dan keunikan budaya. Selain itu menjaga dan melestarikan keindahan alam dalam hal ini Pantai Mulut Seribu, dengan tidak membuang sampah sembarangan. Membudayakan kesadaran pariwisata melalui kesadaran akan sapta pesona oleh masyarakat.

d. Strategi W-T (Weakness-Threat)

Memaksimalkan pelayanan kepada wisatawan serta melengkapi fasilitas yang kurang memadai dan membangun koordinasi dan komunikasi yang baik antara pengelola wisata dengan Pemerintah Daerah serta masyarakat sekitar. Meningkatkan Pendidikan, pengetahuan, dan keterampilan masyarakat setempat sebagai penunjang kegiatan wisata. Pemerintah juga harus kembali memberikan sosialisasikan tentang program pengembangan wisata kepada masyarakat Desa Daiama, agar masyarakat lebih memahami tentang program tersebut sehingga dapat direalisasikan oleh masyarakat dalam pengembangan DTW Pantai Mulut Seribu tersebut.

Berikut merupakan empat strategi utama dalam mengembangkan pariwisata berkelanjutan pada DTW pantai Mulut Seribu yang berbasis wisata bahari. 


\section{Penutup}

Berdasarkan hasil penelitian tentang strategi pengembangan pariwisata berkelanjutan pada daya tarik wisata bahari pantai Mulut Seribu Desa Daiama Kabupaten Rote Ndao, maka pengembangan layak dilakukan mengacu pada hasil penelitian yang berada pada kuadran 1. Pengembangan dilakukan mengacu pada konsep pariwisata berkelanjutan melalui pengembangan potensi wisata alam dan persiapan infrastruktur, promosi, perbaikan SDM dan pemberdayaan masyarakat lokal. Berdasarkan analisis SWOT, langkah yang dapat dirumuskan dalam menggunakan kekuatan dan memanfaatkan peluang yaitu adanya kerjasama dengan pihak pemerintah, masyarakat dan usaha pariwisata yang ada, dengan berinovasi dalam memberdayakan hasil pangan untuk dijadikan oleh-oleh. Pengembangan kelembagaan dan pendidikan, pelatihan manajemen pariwisata dan pengadaan sosialisasi kepada masyarakat lokal agar dapat membuka peluang dan kesempatan kerja bagi masyarakat lokal. Salah satu bentuk nyata yang sudah diterapkan adalah dengan melaksanakan festival mulut seribu.

Dalam pengembangan pariwisata pantai Mulut Seribu dikatakan berkelanjutan apabila kerjasama dan partisipasi antar pihak staheholders ditingkatkan dalam proses perencanaan, pengembangan, dan pengelola sesuai dengan perannya masing-masing sehingga bisa mencapai hasil dan tujuan yang diharapkan. Partisipasi dari masyarakat lokal perlu dikedepankan karena masyarakat lokal yang bersentuhan langsung dengan keadaan dan keberadaan lokasi wisata pantai Mulut Seribu.

\section{Daftar Pustaka}

Dewi, M. H. U. (2013). Pengembangan desa wisata berbasis partisipasi masyarakat lokal di Desa Wisata Jatiluwih Tabanan, Bali. Jurnal Kawistara, 3(2).

Clark, V. L. P., \& Creswell, J. W. (2008). The mixed methods reader. Sage. 
Fandeli, Chafid dan Muhammad Nurdin. 2005. Pengembangan Ekowisata Berbasis Konservasi di Taman Nasional. Fakultas Kehutanan UGM, Pusat Studi Pariwisata UGM, dan Kantor Kementerian Lingkungan Hidup. Yogyakarta.

Harris, P. G. (2012). Environmental policy and sustainable development in China: Hong Kong in global context. Policy Press

Lewis, J. 2003. Design Issues. In Qualitative Research Practice: a Guide for Social Science Student Researcher (eds.) Jane Ritchie and Janes Lewis. London: SAGE Publications

Nistyantara, L. A. (2011). Strategi pengelolaan Taman Nasional Kelimutu melalui pendekatan Co-Management [tesis]. Bogor: Sekolah Pascasarjana, Institut Pertanian Bogor.

Moleong, L. J. (2007). Metode penelitian kualitatif.

Nugraha, Y. E. (2019). ANALISIS PASAR WISATAWAN MANCANEGARA PENGGUNA LAYANAN WISATA MEDIS DI BALI. Tourism-Jurnal Pariwisata, 2(2), 90-99.

Nugraha, Y. E., Paturusi, S. A., \& Wijaya, N. M. S. (2019). Kualitas Layanan Wisata Medis Yang Mempengaruhi Kepuasan dan Loyalitas Wisatawan Mancanegara Di Bali. Jurnal Master Pariwisata (JUMPA), 348-370.

Rangkuti F. 2006. Analisis SWOT Teknik Membedah Kasus Bisnis (Reorientasi Konsep Perencanaan Strategis untuk Menghadapi Abad 21). PT. Gramedia Pustaka Utama. Jakarta.

Suansri, P. (2003). Community based tourism handbook. Bangkok: Responsible Ecological Social Tour-REST.

Sugiyono. 2015. Metode Penelitian Manajemen: Pendekatan Kuantitatif, Kualitiatif, Kombinasi (mix methods), Penelitian Tindakan (Action Research), Penelitian Evaluasi. Bandung: Alfabeta.

UU No. 10 Tahun 2009 mengenai Kepariwisataan

\section{Profil Penulis}

Yudha Eka Nugraha, S.Kesos., M.Par. Lahir di Pati, 04 April 1991. Menyelesaikan menyelesaikan program S1 Kesejahteraan Sosial Universitas Indonesia pada tahun 2014. Kemudian melanjutkan studi S2 Kajian Pariwisata pada tahun 2018. Pada tahun 2017 penulis sempat mengikuti Program Joint Degree ke Hochschule Stralsund Jerman. Sejak tahun 2019, penulis menjalankan tugas sebagai Pegawai Negeri Sipil di Jurusan Pariwisata Politeknik Negeri Kupang sebagai Dosen Asisten Ahli dan mengampu mata kuliah Pariwisata Berbasis Masyarakat. Penulis dapat dihubungi melalui surat elektronik yudhaekanugraha@gmail.com. 